MARLENA KILIAN

Faculty of Educational Sciences

Cardinal Stefan Wyszyński University

Warsaw (Poland)

ORCID ID: http://orcid.org/oooo-ooo2-7285-9784
Forum Pedagogiczne $2018 / 2$

Wpłynęło: 24.01.2018 Zatwierdzono do druku: 26.09.2018 DOI: 10.21697/fp.2018.2.17

\title{
INDIVIDUAL AND SOCIAL CONSEQUENCES OF OLD AGE STEREOTYPES*
}

\begin{abstract}
In the era of aging societies the consequences of old age stereotypes seem to be underestimated. The aim of the article is to present the influence of old age stereotypes on aging individuals and the society as a whole, based on the available empirical data. The article begins with a definition of a stereotype and then it analyses individual and social consequences of old age stereotypes. The analysis of the cited empirical data about the consequences of these stereotypes leads to a belief that positive changes in ageing stereotypes can result in improved physical, psychological and social functioning of elderly people and a realistic identification of their potential may lead to a better utilization of their impact in the society.
\end{abstract}

Keywords: aging, old age, stereotypes, age-related stereotypes, ageism.

\section{Introduction}

Even though the current scientific accomplishments show that old age can be successful i.e. healthy, productive and satisfactory; stereotyping, prejudice and discrimination of the elderly seem to be escalating in strength and popularity. Today, when people live longer and elderly population is on the rise on national and international level, the phenomenon of ageism seems to be still underestimated, especially in regard to its consequences on individual and social level.

Ageism affects attitude and behaviour towards the elderly as well as their own self-esteem and their competence. The consequences of ageism are especially harmful to an individual, but also to the elderly as a group and society as a whole.

* Artykuł jest rozszerzoną wersją tekstu napisanego w języku polskim pt. Starość nie radość. Skutki stereotypizacji starszego wieku, który został opublikowany w: A. Fidelus (red.), Od stereotypu do wykluczenia, Wydawnictwo Kardynała Stefana Wyszyńskiego, Warszawa 2014, s. 143-161. 
Stereotypes present in society about old age can affect functional abilities, behaviour and health of older people. Ageism can lower these people's self-esteem and their expectations about life standards as well as received medical services. As an age group these people do not voice their real needs loudly enough and form interest groups that would strive towards their realization. Not being able to make use of the full potential of their older citizens is detrimental to an ageist society. (Kilian 2004)

The aim of the article is to present the influence of old age stereotypes on aging individuals and the society as a whole, based on the available empirical data. The article begins with a definition of a stereotype, further analyses individual and social consequences of old age stereotypes.

\section{Stereotyping Old Age}

The analysis of stereotyping consequences for the elderly, including ageism, requires several definitions. A stereotype is a simplified and abbreviated form of thinking that allows every member of a given group to be attributed with identical features in the process of mechanical categorisation. Assigning a person to a given category allows automatic transfer of this group's common characteristics onto him through generalization. These collectively voiced cognitive patterns are based on general believes and do not take individual differences into account. Stereotypes are used for automatic acquisition of a wide range of information about a given person based on his one trait - category affiliation. Assigning people to social categories that are linked to stereotypes is carried out through the process of stigmatization i.e. social demarcation of a group or stigmatized people or so called labelling. Stigmatization underlines an exaggerated trait of a given person based solely on its affiliation to a given social group excluding other groups. Being stigmatized, a person develops expectations to observe behavioural norms consistent with an assigned stigma.

Prejudice based on stereotypes allows the assessment of a given person even before we meet them. It can result in a discriminatory behaviour i.e. to negative and unjustified actions aimed against that person based only on its affiliation to a group that is discriminated against. To simplify, stereotypes are cognitive and prejudice is affective, while discrimination is has a behavioural component.

Negative stereotypes about the elderly are also based on generalisation and simplification, contributing to the false image of this group. Older people are perceived as representatives of a certain group, not as individuals, which is why they are attributed with negative traits. On the negative side, the most popular traits attributed to the elderly include: awkwardness, rigidity, being old fashioned, sickliness, disability, loss of sexual functions, uselessness, isolation, loneliness, sadness. (Palmore 1999) According to a stereotypical image, the elderly are characterised by deteriorated physical and mental abilities and are incapable of living independent, productive and satisfactory lives, being a burden for their family as well for the entire society. Despite bringing out positive feelings, they are 
associated with a low competence level (Fiske at al. 2002). Stereotypical thinking makes people more inclined to attribute memory loss in the elderly to their incompetence, while in younger people to the lack of attention or tiredness (Erber at al. 1996). Consequently, memory problems in young people are explained by their absent-mindedness, while in case of old age they are automatically linked to chronological age.

Although as a general rule stereotypes are not characterised by a negative tone, they usually evoke negative connotations in relation to elderly people. The term "older person" has a negative semantic load - healthy and active people are not labelled as old. In social awareness there is also a positive image of old age; however, it is not as popular as the negative one. Erdman Palmore (Palmore 1999), an author of classical works on the subject of ageism, has named eight positive stereotypes about elderly people that are present in Western civilization: kindness, wisdom, dependability, affluence, political power, freedom, eternal youth, happiness. In this perspective, non-standard traits or achievements of older people are, however, presented as unusual and due to its peculiarity attract increased public attention. It can be assumed that the positive image of the elderly consist to great extent of political correctness, which demands to avoid the word 'old', however in everyday life people of the third age are the most often referred to as retirees or pensioners.

\section{Individual consequences of aging stereotypes}

Negative stereotypes about old age are acquired since early childhood; however, due to a young age they are characterised by the lack of direct reference and are directed outwards. Over time, with the course of reaching an age objectively or subjectively considered as old, the gradual identification of stereotypical judgement on getting old with views about oneself takes place, which is known as the process of "contamination". (Levy 2003) The following relation was found in this process: the more negative ageing stereotypes are the stronger resistance to identify oneself with elderly people is, sometimes assuming the form of denial (Levy at al.2002).

The above hypothesis, according to which ageing stereotypes are transferred into self-image formed during old age (contamination hypothesis), is confirmed by studies conducted by Becca Levy (Levy 1996). In his experiment, aged people playing a computer game were exposed to positive and negative views on ageing. Stereotypical messages were displayed fast enough to avoid the use of consciousness, which is why the participants did not know the actual goal of the study. Seniors exposed to negative messages e.g. "awkwardness" or "Alzheimer" performed worse in memory tasks compared to those who received positive messages such as "wisdom" or "wise man". Based on the obtained results, it can be concluded that subconsciously activated ageing stereotypes affect self-image indirectly affecting mental functioning of an elderly person. 
As part of another study Becca Levy and Ellen Langer (Levy 1994) decided to establish the influence of cultural differences in regard to ageing stereotypes on memory functioning in old age. Three different groups have been culturally examined: Chinese and hearing-impaired Americans, in which the stereotypes on the elderly were not as widespread as in hearing Americans, who formed a separate group. In each of the three examined group, young adults and aged people constituted half of the participants. The obtained results were surprising and are now regarded as part of the canon of empirical scientific achievements on the subject of mental functioning in the elderly. It was shown that aged Chinese and hearing-impaired people obtained better scores in memory tests than nonhearing-impaired Americans (among young adults the results were equal), which suggests that memory loss in the elderly might be influenced by social processes. If memory loss was solely biological - there should be no differences between the examined groups. It is therefore possible that existing aging stereotypes are becoming a self-fulfilling prophecy.

Although there are numerous publications mentioning memory loss with age, the inevitability of these mental functioning changes, which can be significantly influenced by negative stereotypical expectations regarding the process of ageing, is increasingly questioned. Currently, science leaves no doubt that positive expectations regarding old age are linked to better mental functioning and negative ones to deteriorated mental efficiency. According to Ellen Ryan (Ryan 1992), people expecting age-related memory deterioration are more likely to develop memory loss as well as to use adaptive strategies less frequently, avoid challenges and not seek for medical help in case of pathological memory problems. Adapted stereotypes can have a long lasting effect on a person's self-esteem (Major at al. 1998).

People adapt to shared stereotypes not only on a psychological, social and behavioural level, but also in the dimension of physical functioning. This thesis has been confirmed by studies that aimed at determining the influence of stereotypes on the marching speed of aged people. After 30 minute exposure to positive stereotypes, the elderly improved the marching speed and gait patterns. In people exposed to negative stereotypes, there were no measurable changes found. (Hausdorff 1999) The influence of views about ageing on being physically active was also examined. Sandra O'Brien Cousins (O'Brien Cousins 200o) found that older women avoided physical activity because of shared negative stereotypes about the physical condition of the elderly. Despite being aware of beneficial effects of exercise on health, shared stereotypes emphasising dangers related to physical activity were used as an excuse to abstain from it. The existence of correlation between views about old age and physical activity was also shown by Catherine Sarkisian et al. (Sarkisian at al.2005) - seniors who spent more time exercising were more likely to express greater expectations about old age compared to aged people who do not exercise.

The relation between ageing stereotypes and biological functioning of an older person in regard to hearing abilities were also examined by Levy et al (Levy at al. 
2006). The participants aged 70-96 who shared more negative stereotypes in relation to appearance showed deteriorated hearing three years after the first examination. This indicates psychosocial aetiology of biological changes, which the hearing loss is. The belief that old age translates into poor health can cause real health problems in the future. Therefore, stereotyping is a key social health determinant. This relationship can be explained by increased commitment in preventive health measures in people characterised by more positive self-perception (Levy at al. 2002). Negative stereotypes can, in fact, shorten one's life, which has been mentioned in a widely cited longitudinal studies by Levy et al. (Levy at al.2002) conducted over the period of 23 years. It was shown that people perceiving old age more positively lived 7.5 years longer than people who had more negative views on this subject, regardless of factors such as sex, race, socioeconomic status, loneliness, subjective health condition or functional abilities. Life expectancy was affected by the will to live, which was stronger in people who expressed more positive attitude towards old age. This result seems to be surprising when compared to the influence of studies on physical factors (cholesterol levels) or behavioural (e.g. physical exercises) that prolonged the live by up to four years (Levy 2003).

The above mentioned series of studies were focused on establishing the stereotyping consequences taking place outside consciousness. The results of the indirect activation of stereotypes has been laid out in stereotype threat theory by Claude Steele et al. (Steele 1997). It describes anxiety that escalates upon the activation of negative self-stereotypes resulting in decreased task efficiency (Steele 1997). This threat and the resulting deteriorated task efficiency may be caused by the fear to confirm negative stereotypes assigned to a group, to which a given person belongs. The threat of being evaluated from the perspective of negative stereotypes can result in increased pressure during an action that can negatively affect its accomplishment, which confirms stereotype that that person was trying to avoid. In a pioneering study on the influence of self-stereotype activation on behaviour conducted by Claude Steele and Joshua Aronson (Steele at al. 1995), it was shown that the activation of Afro-American stereotypes led to deteriorated academic results obtained by African Americans at universities. A similar decrease in task performance under the conditions of being threatened by a stereotype was found in woman examined mathematically. Exposed to a stereotype, according to which men score higher in this subject, women performed worse than men, while women who were not exposed to that stereotype were dealing equally well. (Spencer at al. 1999)

The stereotype threat theory gives an explanation to the situation where an elderly person deals worse with a task after the activation of aging stereotypes or a threat associated with their ageing. In one of studies (Desrichard at al.2005), it was shown that mere awareness of the fact that one's memory is being testes decreases the efficiency of performing in memory tasks. It shows that the context of the study correlates with obtained results. The influence of the threat is not universal - this 
effect is stronger in people who have a good opinion on their memory (Hess at al. 2003), are at the age that is perceived as the beginning of old age (Hess at al. 2006), who reported subjective feeling of being threatened (Chasteen at al. 2005).

The issue of assessing the influence of stereotypes on self-perception was raised in two opposing theories: labelling theory and resilience theory. According to the oldest of the mentioned theories - labelling theory (Scheff 1966) - negative aging stereotypes create a negative image of the elderly encouraging younger people to stigmatizing behaviours towards them. The internalization of negative aging believes results in the elderly attributing other people's negative behaviour to internal determinants rather than external factors. The elderly may start to behave in accordance with adopted stereotypes, which may result in psychological damage as well as negative self-perception and even mental disorders. Although the longitudinal research has shown that internalised negative ageing stereotypes can lead to a decrease in self-esteem (Coleman at al. 1993), it should be noted that this influence may depend on subjective self-perception as an old or middle-aged person (Ward 1977).

In counterpoint to the theories mentioned above that seek to demonstrate negative influence of stereotypes on the functioning of the elderly, some concepts, indicating the existence of protective mechanisms against experienced discrimination, have been developed. Resilience theory is one of the most widely discussed ones. It claims that in the situation when negative stereotypes can threaten the positive self-perception of the elderly, protective mechanisms are activated to counteract the passive acceptation of negative information. Elderly people may reject a negative stereotype as inept for the general population of the elderly or themselves i.e. due to finding the source of the message unreliable or the exclusion of oneself from the category of aged people. They can also perform social comparison in a top-down way, finding an imaginary group of elderly people in a worse situation and apply the negative information to this subgroup (e.g. older residents of nursing homes). (Heidrich 1993) In this case, negative ageing stereotypes are a reference point highlighting their virtues against stigmatized seniors, which helps to improve their self-esteem as those who are the exception to the rule (Heckhausen 1997). Other studies have confirmed higher self-esteem and life satisfaction among the elderly, who viewed others as inferior (Essex at al. 1989). Selective choice of less fortunate social referents is aimed at improving one's own position. Addressing negative stereotypical information to peers rather than to oneself improves positive self-perception but deteriorates the general perception of one's peers (Heckhausen at al. 1997). Downward social comparison is an important mechanism of the psychological adaptation of the elderly. The resilience theory is based on a strong empirical foundation showing that older people do not assign negative stereotypes to themselves and do not perceive themselves less positively than younger people.

Discounting theory describes protective mechanisms against group discrimination in a different manner (Crocker at al.1989); according to his theory 
discrimination results in the creation of group identification amongst the oldest members of society that attenuates the effect of perceived discrimination. Ageing prejudice against the elderly in an individual dimension is perceived in group categories, which protects them against facing personal factors responsible for being rejected. An individual is passed over in the evaluation of causes for discriminatory behaviour, which protects their psychological well-being. The experience of group discrimination can mitigate the effect of individual rejection, as people do not feel lonely in their difficult situation.

The consequences of discrimination based on age, wellbeing and group identification is also explained by the rejection-identification model, developed on the foundations of social identity theory) (Tajfel at al. 1986). In this perspective, the perception of one's group as discriminated against causes psychological damage, which is dealt by strengthening of identification with a group of low status, which they belong to, which in return mitigates negative consequences of experienced discrimination (Bat-Chava 1994). The strengthening of identification with an excluded group has a positive impact on their physical wellbeing. This relation was found in African Americans (Redersdorff at al. 2004), women (Branscombe at al. 1999), foreign students (Schmitt at al. 2003) and also in the elderly (Garstka at al. 2004). For young adults, however, the perception of age discrimination is not connected to either psychological well-being or group identification, which can be explained by their temporary participation in a group of low status, while in case of old age it is permanent. The identification with a group is determined by the stability of this relationship. It is not possible for the elderly to leave their group of low status, which strengthens identification with that group and as a result mitigates negative results of perceived discrimination. Therefore, the discussed model of rejection and identification admits that there is a negative influence of experienced discrimination on psychological condition and positive influence of strengthened identification with a group discriminated against (Garstka at al. 2004).

The cited empirical literature suggests that ageing stereotypes have a negative influence on the functioning of elderly people when activated outside a person's consciousness as well as when it has to be faced consciously. The fact that the internalization of ageing stereotypes has an undoubtedly negative impact on the functioning of seniors is a baseline for the development of theories indicating the existence of protective mechanisms against assimilation of negative stereotypes, although there is some divergence in conceptual and empirical dimensions. In rejection-identification model and in the perspective of discounting against experienced discrimination emphasis has been placed on group identification. In rejection-identification model the perception of discrimination stimulates the identification with a minority group, while discounting perspective shows different interpersonal influence - it is identification with a minority group that can stimulate the perception of discrimination. In rejection-identification model, the defence mechanism consists in strengthening group identification, in resilience 
model protection from negative influence of stereotypes requires leaving the group discriminated against. Despite ageism and age-related changes, with which older people have to deal with, most of them retains a positive self-image, which is called "well-being paradox". This supports theories describing the existence of defence mechanisms against experienced discrimination (Mroczek at al.1998). After all, the retention of positive self-image and high level of subjective well-being is one of the aspects of successful ageing.

\section{Social consequences of ageing stereotypes}

Stereotypes are characterised by opinion-forming abilities and can affect behaviour towards social groups that are categorised and perceived from the perspective of negative believes. That seemingly innocent simplifications or exaggerations lead to the formation of the image of old age that is far from the truth, and as a consequence, in case of negative stereotypes, even to ageism (also known as gerontophobia), which is defined as prejudice against older people. Today, many problems of the elderly does not result directly from biological ageing effects, but from social attitudes towards old age. The consequences of ageing stereotypes, including ageism, should be therefore considered not only in an individual dimension, but also in a social one.

Currently, ageism can be found in all aspects of social life. It is expressed in the form of stereotypes verbally, through gestures, behaviour and customs. It is present at homes, in the education system, at work, media, hospitals, nursing homes and government circles. It is shown by children, the youth, adults and aged people themselves. The sources of ageism are believed to be found in prejudice against old age and older people. Originally, ageism was defined by the creator of the term, Robert Butler, as "[...] prejudice by one age group toward other age groups." (Butler 1969, s. 243). A newer definition defines ageism as “[...] the process of systematic stereotyping and discrimination against people because they are old." (Butler 1975, s. 22). Erdman Palmore (Palmore 1999) extended the meaning of ageism to: prejudice, discrimination, stereotypes and attitudes. Recently, a new alternative version of the definition has been developed, which consolidates older and newer theories dealing with this phenomenon. According to this complex definition: „[...] negative or positive stereotypes, prejudice and/or discrimination against (or to the advantage of ) elderly people on the basis of their chronological age or on the basis of a perception of them as being 'old' or 'elderly'. Ageism can be implicit or explicit and can be expressed on a micro-,meso- or macro-level. The concept includes the classic social psychological components in the form of; 1) cognitive (stereotypes), 2) affective (prejudice), 3) and behavioural components (discrimination), in other words, how we on the basis of the chronological age or age categorization mistakenly; 1) think of, 2) feel for, 3) and act on the aging human being. Furthermore, ageism can operate both consciously (explicitly) and unconsciously (implicitly) and it can manifest itself on three different levels; the 
individual (micro-level), in social networks (meso-level) and on institutional and cultural level (macro-level)." (Iversen at al. 2009, s. 15). This definition involves the following key dimensions: mental, affective, behavioural of positive and negative ageism, conscious and unconscious ageism as well as typological division of ageism into micro, meso and macro.

Ageism involves negative attitudes towards elderly people, which are degrading and dehumanising them. Being an example of stereotypical thinking, ageism avoids to take into account traits of an individual instead categorising the elderly as a group. Ageism is compared to sexism and racism due to common aetiology - they are derived from stereotyping, prejudice and discrimination of minority groups. Although the term covers all the age groups, it is the most often used in relation to the discrimination of aged people. The fact that ageism is expressed by people, who with the passage of time are approaching the same age category that they discriminate against is its distinctive feature. In this sense, everyone can become the target of age discrimination at some point. (Palmore 2001)

Ageism is derived from deep-rooted believes formed by social, cultural, political and economic factors. The cult of youth in western culture rejects old age and its manifestations imposing its caricaturized form defined by stereotypes. This is why the old age has become a period of life that is undesirable and therefore is avoided and delayed. The cult of youth and ageism are becoming the driving force for development in many fields of economy, science and medicine. A whole new industry sector, which capitalize on sales of products delaying or masking ageing effects as well as medicine, which normally is supposed to help the sick, deal with fighting the signs of ageing. In the latter area ageing, stereotypes expressed by specialists and seniors themselves led to the acceptation of pathological changes experienced during late years of life as natural and being inherent to this period of life, which do not require treatment. Older people are less likely to be referred to specialist consultation or examination due to advanced age and the quality of received medical services is lower. As a result, older people are the most medically neglected group. (Derejczyk 200o) The recognition of pathological changes due to ageing as equal to natural changes leads to negligence in prevention, diagnosis, treatment and rehabilitation, which are regarded as useless. (Kilian 2007)

Modern medicine shows interest in extending human life and to a lesser extent in prolonging medical fitness, which can ensure its higher quality. As a consequence, old age is strongly associated with sickness and awkwardness. Furthermore, the possibility of medical intervention is less probable in case of chronic diseases typical of older age and closely related to disabilities with medical efforts focused on acute conditions typical of young adulthood. The reason behind that is the fact that difficult to treat chronic diseases are not inevitable part of ageing process, and "healthy ageing" and "successful ageing" are not only oxymoron. (Kilian 2009) Despite the advanced stage of demographic process of the ageing of Polish society 
and contrary to economic circumstances, medical and rehabilitation services are still to a large extend focused on the needs of younger patients rather than older.

Similarly, ageing stereotypes and ageism lead to a deterioration in rehabilitation standards for the elderly. The fact that there is no system for adjusting techniques and methods for characteristics and abilities of aged people results not only from not being aware of them, but also from deliberate negligence in the field of rehabilitation. The area of disease and disability prevention and early diagnosis of senile disability as well as early rehabilitation intervention are also neglected. Seniors are inadequately equipped with rehabilitation aids and insufficiently trained. (Kilian 2004) The failure to notice the needs of disabled and aged patients results in neglecting the issue of modification of their environment to meet their expectations not only in a public dimension, but also in specialist care centres such as surgeries and nursing homes. The lack of gerontological staff training accompanied by the ignorance of the needs of older patients is the reason why these needs remain unfulfilled. Infantilization of the contact with the elderly, which manifests through overprotectiveness, frivolous approach, limitation of independence and responsibility.

Demographic and individual ageing education should be based on science, which, however, does not show sufficient interest in gerontological issues despite the demand generated by rapidly progressing ageing. The science focuses predominantly on prejudice against race and sex (racism and sexism), while ageism as a form of ageing prejudice still remains beyond the area of mainstream scientific research, which in itself is a form of ageing discrimination. The lack of gerontological journal articles is explained by e.g. the shortage of research carried out. As a result, scientific literature that shapes believes on the subject of old age duplicates stereotypes, e.g. due to failure to distinguish between natural and pathological ageing, loss of mental abilities is perceived in universal categories. There is no scientific subdisciplines on old age. Negative attitudes towards ageing influence professional decisions, e.g. nursing students show negative attitudes towards the elderly (Courtney at al.200o), as well as are reluctant to work with them (Dellasega at al. 1991). As a result in many professions such as a GP, social worker, psychologist, counsellor and others there is not enough qualified specialists who could work with the elderly.

In some areas discriminatory practices assume an institutionalized form e.g. determination of fitness to work based on chronological age, regardless of qualifications, professional experience and work efficiently. As an invention of industrialised society, retirement allows older employees to be removed as part of the fight against unemployment in order to free up space for younger employees perceived as more productive. The discrimination of elderly people is seen from the moment of recruitment (e.g. highlighting young age of applicants), through their career path (promotion, training) to retirement. This ageist limitation of professional prospects of aged employees does not allow for the full utilization of human resources. In individual perspective, discrimination at a workplace results 
in decreased productivity, diminished commitment in work and less satisfaction from professional creativity (Orpen 1995).

Stereotypes about elderly workers describe them as less creative, less efficient, more prone to work accidents, unable to master the latest technologies, more difficult to train, sickly and interested in part time jobs. Elderly people are laid off because according to their employers it is more beneficial to hire young people who have lower expectations, are satisfied with lower salaries and can work longer and more efficiently. The studies on the subject, however, contradict this opinion. It was proven that the productivity curve reaches its peak at 40-60 years and then drops, which is why employees in their sixties are more productive than those in their thirties. (Cleveland at al.1996) It was shown that professionally active seniors are more productive, are less likely to change their employer and less often take days off (Segrave 2001). In elderly people who do not suffer from chronic diseases, there is a lower risk of changing work and being absent. They are also less likely to have an accident at work. (Cleveland at al.1996)

Stereotypical perception of old age allows people to accuse elderly people of stealing young people's jobs, while retirement is associated with economic burden on society. The modern principle of usefulness is based on production efficiency - if an older person does not directly support society financially it is perceived as useless. Retirement constitute $1 / 4$ and sometimes as much as $1 / 3$ of entire lifespan, which is why the role of society in relation to seniors and the utilization of their potential should be widely discussed. Undoubtedly, the perception of the elderly in the perspective of stereotypes does not allow their potential to be discovered. The fact that pensioners are younger, healthier and better educated that today compared to past generations of elderly people is highly underappreciated. They have more time available, better skills, and the will to voluntarily work for the benefit of others. It was shown that elderly people attach greater importance to voluntary work than younger people. Voluntary work is not only beneficial to society but also to elderly volunteers, who show greater satisfaction with life, physical and mental well-being, sense of self-realization and usefulness. (Van Willigen 2000)

Negative stereotypes can have a destructive impact on socialization of young with elderly people. According to the dehumanised stereotype of old age young people perceive the elderly as less valuable and avoid their company. Ageism highlighting differences between young and elderly in favour of young allows new generation to stop identifying themselves with elderly people as human beings. The elderly are often perceived in social perspective not as "we" but as "them", destroys the unity of generations. (Butler 1975) The gerontophobic reflex rejected old age not only with associated diseases, disability or appearance deterioration but also with wisdom and experience inherent to this stage of life. Currently, it is scientific knowledge that decides on economic and social status, which encourages young people to perceive the older generation as those who know more and better. It is not only the scientific knowledge gained by the older generation that is rejected but 
also universal wisdom gained in the course of their lives. Young people distance from the experience of the elderly and from what they represent. As a result a gap in intergenerational communication is created. Young and older generations form opposing social groups, although in fact they complement and need each other. The results of age discrimination in this area clearly indicate the need to build a multigenerational society without age discrimination and segregation.

\section{Conclusion}

Many years ago, Edward Rosset wrote: "I believe that one can come to terms with poor health in their old age, as well as, however not without difficulty, get used to worse financial situation after retiring, one can even come to terms with the thoughts of inevitable but possibly near death. However, what one cannot come to terms with is social and moral degradation, being alienated from society with the feeling of uselessness and lack of respect from one's community.". (Rosset 1974, s. 43) Since when those reflection were written down, the process of the relegation of the elderly to the margin of social life has deepened with its all consequences. The analysis of the cited empirical data on the consequences of ageing stereotypes leads to a belief that positive changes in ageing stereotypes can result in improved physical, psychological and social functioning of elderly people and based on realistic identification of their potential in better utilization of their impact. It is paramount to disclose the truth about the elderly, which is why attempts to excessively emphasize positive stereotypes that would present a caricatured image of old age just like negative ones should be avoided. The disclosure of the real image of old age will allow real, changing in time human needs to be met and to support the human being in his or her lifelong development beneficial for the individual and the society as a whole.

\section{References}

Bat-Chava Y. (1994). Group identification and self-esteem in deaf adults. "Personality and Social Psychology Bulletin", 20, 494-502.

Branscombe N. R., Schmitt M., Harvey R. (1999). Perceiving pervasive discrimination among African-Americans: Implications for group identification and well-being. "Journal of Personality and Social Psychology", 77(1), 135-149.

Butler R.N. (1969). Age-ism: Another form of bigotry. "The Gerontologist”, 9(4), 243-246.

Butler R. N. (1975). Why Survive? Being old in America. New York: Harper and Row. Courtney M., Tong S., Walsh A. (200o). Older patients in acute care settings: Rural and metropolitan nurses' knowledge, attitudes and practices. "Australian Journal of Rural Health", 8(1), 94-102. 
Crocker J., Major, B. (1989). Social stigma and self-esteem: The self-protective properties of stigma. "Psychological Review", 96(4), 608-630.

Coleman P., Aubin A., Robinson M., Ivani-Chalian C., Briggs R. (1993). Predictors of depressive symptoms and low self-esteem in a follow-up study of elderly people over 10 years. "International Journal of Geriatric Psychiatry", 8(4), 343-349.

Chasteen A.L., Bhattacharyya S., Horhota M., Tam R., Hasher L. (2005). How feelings of stereotype threat influence older adults' memory performance. "Experimental Aging Research", 31(3), 235-260.

Cleveland J.N., Shore L.M. (1996). Work and employment. In: Birren J.E. (ed.). Encyclopedia of gerontology, Vol 2, New York: Academic Press.

Derejczyk J. (200o). Geriatria a reforma ochrony zdrowia w Polsce. „Służba Zdrowia”, 61-64, 2954-2957, August 3-14.

Dellasega C., Curriero F. C. (1991). The effects of institutional and community experiences on nursing students' intentions toward work with the elderly. "Journal of Nursing Education", 30(9), 405-410.

Desrichard O., Kopetz C. (2005). A threat in the elder: The impact of task instructions, self-efficacy and performance expectations on memory performance in the elderly. "European Journal of Social Psychology", 35(4), 537-552.

Essex M., Klein M. (1989). The importance of self-concept and coping resources in explaining physical health status and depression among older women. "Journal of Aging and Health", 1(3), 327-348.

Erber J.T., Prager I.G., Williams M., Caiola M.A. (1996). Age and forgetfulness: Confidence in ability and attribution for memory failures. "Psychology and Aging", 11(2), 310-315.

Fiske S.T., Cuddy A.J.C., Glick P.S., Xu J. (2002). A model of (often mixed) stereotype content: Competence and warmth respectively follow from perceived status and competition. "Journal of Personality and Social Psychology", 82(6), 878-902.

Garstka T.A., Schmitt M.T., Branscombe N.R., Hummert M.L. (2004). How young and older adult differ in their responses to perceived discrimination. "Psychology and Aging", 19, 326-335.

Hausdorff J.M., Levy B.R., Wei J.Y. (1999). The power of ageism on physical function of older persons: Reversibility of age-related gait changes. "Journal of the American Geriatrics Society", 47(11), 136-139.

Hess T.M., Auman C., Colcombe S.J., Rahhal T.A. (2003). The impact of stereotype threat on age differences in memory performance. "Journal of Gerontology: Psychological Sciences", 58(1), 3-11.

Hess T.M., Hinson J.T. (2006). Age-related variation in the influences of aging stereotypes on memory in adulthood. "Psychology and Aging", 21(3), 621-625.

Heidrich S., Ryff C.D. (1993). The role of social comparison processes in the psychological adaptation of the elderly. "Journal of Gerontology, Psychological Sciences", 48, 127-136. 
Heckhausen J., Brim O.G. (1997). Perceived problems for self and others: Selfprotection by social downgrading throughout adulthood. "Psychology and Aging", $12(4), 610-619$.

Iversen T.N., Larsen L., Solem P.E. (2009). A conceptual analysis of Ageism. "Nordic Psychology", 61(3), 4-22.

Kilian M. (2007). Niepełnosprawni w społeczeństwie. „Polityka Społeczna”, 404$-405(11-12), 14-18$.

Kilian M. (2009). Geragogika specjalna w dobie starzenia się społeczeństw. In: Dycht M., Marszałek L. (eds.). Dylematy (niepełno)sprawności - rozważania na marginesie studiów kulturowo-społecznych. Warszawa: Wydawnictwo Salezjańskie.

Kilian M. (2004). Źródła ageizmu i jego przejawy we współczesnym świecie. „Gerontologia Polska”, 12(3), 125-128.

Levy B.R. (2003). Mind matters: cognitive and physical effects of aging self-stereotypes. "Journal of Gerontology: Psychological Sciences", 58(4), 203-211.

Levy B.R., Banaji M.R. (2002). Implicit ageism. In: Nelson T. (ed.). Ageism: Stereotyping and prejudice against older persons.Cambridge: MIT.

Levy B. (1996). Improving memory in old age through implicit self-stereotyping. "Journal of Personality and Social Psychology", 71(6), 1092-1107.

Levy B., Langer E. (1994). Ageing free from negative stereotypes: Successful memory in China and among the American deaf. "Journal of Personality and Social Psychology", 66(6), 989-997.

Levy B., Slade M.D., Gill T.M. (2006). Hearing decline predicted by elders' stereotypes. "Journal of Gerontology: Psychological Sciences", 61(2), 82-87.

Levy B.R., Slade M.D., Kasl S.V. (2002). Longitudinal benefit of positive self-perceptions of aging on functional health". "Journal of Gerontology: Psychological Sciences", 57(5), 1-9.

Levy B.R., Slade M.D., May J., Caracciolo E. (2006). Physical recovery after acute myocardial infarction: Positive age self-stereotypes as a resource. "International Journal of Aging and Human Development", 62(4), 285-301.

Levy B.R., Slade M.D., Kunkel S.R., Kasl S.V. (2002). Attitudes and social cognition. "Journal of Personality and Social Psychology", 83(2), 261-270.

Major B., Spencer S., Schmader T., Wolfe C., Crocker J. (1998). Coping with negative stereotypes about intellectual performance: The role of psychological disengagement. "Personality and Social Psychology Bulletin", 24(1), 34-50.

Mroczek D.K., Kolarz C.M. (1998). The effect of age on positive and negative affect: A developmental perspective on happiness. "Journal of Personality and Social Psychology", 75(5), 1333-1349.

O'Brien Cousins S. (2000). "My heart couldn't take it": Older women's beliefs about exercise benefits and risks. "Journal of Gerontology: Psychological Sciences", 55(5), 283-294. 
Orpen C. (1995). The effects of perceived age discrimination on employee job satisfaction, organisational commitment, and job involvement. "Psychology: A Quarterly Journal of Human Behaviour", 32(3-4), 55-56.

Palmore E.B. (1999). Ageism: Negative and Positive. New York: Springer Publishing Company.

Palmore E. (2001). The ageism survey: First findings. "The Gerontologist", 41(5), $572-575$.

Ryan E.B. (1992). Beliefs about memory across the life span. "Journal of Gerontology: Psychological Sciences", 47, 41-47.

Redersdorff S., Martinot D., Branscombe N. (2004). The impact of thinking about group-based disadvantages or advantages on women's well-being: An experimental test of the rejection-identification model. "Current Psychology of Cognition", 22(2), 203-222.

Rosset E. (1974). Starzenie się społeczeństw - problem demograficzny XX wieku. In: Problemy ludzi starych $w$ Polsce, Warszawa: Państwowe Wydawnictwo Ekonomiczne.

Sarkisian C.A., Prochaska T.R., Wong M.D., Hirsh S.H., Mangione C.M. (2005). The relationship between expectations for aging and physical activity among older adults. "Journal of General Internal Medicineę, 20(10), 911-915.

Steele C.M. (1997). A threat in the air: How stereotypes shape intellectual identity and performance. "American Psychologist", 52(6), 613-629.

Steele C.M, Aronson J. (1995). Stereotype threat and the intellectual test performance of African Americans. "Journal of Personality and Social Psychology", 69(5), 797-811.

Spencer S., Steele C.M., Quinn D. (1999). Stereotype threat and women's math performance. "Journal of Experimental Social Psychology", 35(1), 4-28.

Scheff T. (1966). Being Mentally Ill. Chicago: Aldine.

Schmitt M.T., Spears R., Branscombe N.R. (2003). Constructing a minority group identity out of shared rejection: The case of international students. "European Journal of Social Psychology", 33(1), 1-12.

Segrave K. (2001). Age discrimination by employers. Jefferson: Mc-Farland \& Company.

Tajfel H., Turner J.T. (1986). The social identity theory of intergroup behaviour. In: Worchel S., Austin W. (eds.). Psychology of intergroup relations. Chicago: Nelson-Hall.

Ward R.A. (1977). The impact of subjective age and stigma on older persons. "Journal of Gerontology", 32(2), 227-232.

Van Willigen M. (2000). Differential trends among elderly persons and implications for the future. "The Journals of Gerontology", 55(5), 308. 


\section{INDYWIDUALNE I SPOŁECZNE KONSEKWENCJE STEREOTYPÓW DOTYCZĄCYCH STAROŚCI}

Streszczenie: W dobie starzenia się społeczeństw konsekwencje stereotypów na temat starszego wieku wydają się niedoceniane. Celem artykułu jest zaprezentowanie wpływu wiekowych stereotypów na starzejące się jednostki i całe społeczeństwo, w oparciu o dostępne dane empiryczne. W części wprowadzającej zdefiniowano pojęcie stereotypu, następnie omówiono indywidualne i społeczne konsekwencje stereotypów na temat starszego wieku. Analiza przytoczonych danych empirycznych na temat skutków stereotypizacji wieku senioralnego rodzi przekonanie, że pozytywne zmiany w zakresie stereotypowych sądów na temat starszego wieku mogą prowadzić do poprawy funkcjonowania fizycznego, psychicznego i społecznego osób w starszym wieku, z drugiej strony, bazując na realnym rozpoznaniu ich możliwości, lepszego wykorzystania przez społeczeństwo ich potencjału.

Słowa kluczowe: starzenie się, starość, stereotypy, stereotypy na temat starszego wieku, ageizm.

Marlena Kilian - doktor, pedagog specjalny, aktualnie pracuje na Wydziale Nauk Pedagogicznych Uniwersytetu Kardynała Stefana Wyszyńskiego w Warszawie na stanowisku adiunkta. W zakresie naukowo-dydaktycznym zajmuje się problematyką starzenia się i starości w kontekście edukacji oraz niepełnosprawności i rehabilitacji tej grupy wiekowej pacjentów. Obszary dydaktyczno-badawcze: gerontologia społeczna, geragogika i geragogika specjalna, tyflopedagogika. Adres do korespondencji: Wydział Nauk Pedagogicznych UKSW, ul. Wóycickiego 1/3, 01-938 WArszawa. Adres e-mailowy: m.kilian@uksw.edu.pl. 